\title{
Update on the Geographic Distribution of Lutra lutra at the Romanian Black Sea Coast
}

\author{
Daniyar MEMEDEMIN ${ }^{1,4, *}$, Marian TUDOR ${ }^{1}$, Dan COGĂLNICEANU ${ }^{1,4}$, \\ Marius SKOLKA ${ }^{1}$, Gabriel BĂNICĂ ${ }^{3}$, Laurențiu ROZYLOWICZ ${ }^{2,4}$
}

\author{
${ }^{1}$ University Ovidius Constanta, Faculty of Natural Sciences and Agricultural Sciences, Al. Universitatii \\ 1, Corp B, 900470, Constanța, Romania. \\ ${ }^{2}$ University of Bucharest, Center for Environmental Research, 1 Nicolae Bălcescu, 010041, Bucharest, \\ Romania. \\ ${ }^{3}$ Biosys Group, Strada Crinului 33B, 900338, Constanţa, Romania. \\ ${ }^{4}$ Association Chelonia Romania, Bucharest. \\ *corresponding author, email: daniyar_memedemin@yahoo.com
}

Received: October 21, 2016; Accepted: May 6, 2017; Available online: June 21, 2017; Printed: June 30, 2017

\begin{abstract}
We report the occurrence of the European otter (Lutra lutra Linnaeus, 1758) along the entire Romanian Black Sea coast, for the first time. Several sightings were within the harbor and the city of Constanța, indicating that the otter can accommodate to and tolerate high human impact. The report is based on observations made between 2012 and 2015. The species has been previously reported from all Romanian regions but not from the Black Sea coast. The occurrences reported within this article confirm an extension of the range of this Near Threatened species on the Romanian Black Sea coast, most probably due to the increasing of population size from other sources such as the Danube floodplain.
\end{abstract}

Key words. European otter; range expansion; Danube Delta; Natura 2000

\section{INTRODUCTION}

The European otter (Lutra lutra Linnaeus, 1758) is a freshwater mammal with a widespread distribution in Eurasia and north-western part of Africa. It inhabits a large variety of freshwater and coastal habitats as long as food supply and habitats suitable for holts are available (Kruuk, 2006). After 1970s, it was observed a steady decline throughout Europe, mostly due to a variety of threats such as habitat loss, water pollution, disease, roadkill and illegal and accidental killing (Roos et al., 2015). The European decline corresponds with the river management phase characterized by extreme structural engineering measures, e.g., construction of dams, flow regulation, water abstraction, that destroyed most wetlands associated with river floodplains (Ioana-Toroimac et al., 2015). All these threats affected the Romanian populations and the otter suffered the same steady decline (Murariu, 2005). At European Union level, the species is protected by the Habitats Directive (Council Directive 92/43/EEC). In the last decade, it was noticed a recovery of otter populations in Europe, including Romania, mostly due to conservation measures under the Natura 2000 approach and the ban of pesticides and a more environmentally responsive vision in river management (Kruuk, 2006; Klenke et al., 2013; Ioana-Toroimac et al., 2015). However, European otter populations are not fully recovered and IUCN Otter Specialist Group recently re-assessed the species as Near Threatened with a decreasing trend (Roos et al., 2015). In the Romanian Black Sea region, the conservation status is Unfavourable-Inadequate (European Topic Centre on Biological Diversity, 2015). 


\section{MATERIAL AND METHODS}

The European otter is an aquatic carnivore easily to recognize in the water and on the land. The legs are short and the body elongated, adapted for swimming. The fur is thick, brownish-gray and silky. European otter displays whitish-gray colour on the ventral side, chin, throat and chest (Murariu \& Munteanu, 2005). The tail is long and powerful, thick at the base. The muzzle is broad and with long whiskers and presents a slight angle at the top edge of the rhinarium. The feet are webbed and leave a very distinctive track (Auglanier et al., 2008).

Individuals were visually identified after description provided by Auglanier et al. (2008). Additionally, tracks and spraints confirmed the species presence (for details see Kranz, 2000). The locations were registered using handheld GPS. Locations are provided using WGS84 decimal degrees, together with data of observation, locality, and habitats.

\section{RESULTS}

We report 14 occurrence records of European otter from the Romanian Black Sea coast, based on the observations made between 2012 and 2015. We identified European otter in a variety of coastal habitats i.e., Doloșman Cape - Razelm lagoon (ID 1), Histria-Sinoe lagoon (IDs 2,3), Vadu shoreline, fishing port and beach (IDs 4,5,6), Corbu open sea (ID 7), heavily modified Tașaul Lake within a urbanized area (IDs 8,9), Midia port (ID 10), Năvodari on Poarta Albă Midia Năvodari canal (ID 11), Siutghiol lagoon (ID 12), Tabăcărie Lake, the last two within the city of Constanţa (ID 13) and Tuzla Cape on open sea (ID 14) (Tab. 1, Fig. 1, Fig. 2, Fig. 3).

Occurrences of European otter in the Romanian Black Sea region.

Table 1

\begin{tabular}{|c|c|c|c|c|c|}
\hline ID & Year of obs. & Latitude & Longitude & Locality & Habitat \\
\hline 1 & 2015 & 44.758117 & 28.94125 & Doloșman cape & Razelm lagoon \\
\hline 2 & 2015 & 44.547733 & 28.77628 & Histria & Sinoe lagoon \\
\hline 3 & 2015 & 44.547683 & 28.77628 & Histria & Sinoe lagoon \\
\hline 4 & 2013 & 44.431533 & 28.76905 & Vadu & Shoreline, closed fishing port \\
\hline 5 & 2013 & 44.430383 & 28.76827 & Vadu & Shoreline, closed fishing port \\
\hline 6 & 2013 & 44.429400 & 28.76900 & Vadu & Shoreline, beach \\
\hline 7 & 2014 & 44.366867 & 28.70403 & Corbu & Open sea \\
\hline 8 & 2012 & 44.354717 & 28.63493 & Năvodari & Tașaul lagoon, fishing port \\
\hline 9 & 2012 & 44.347983 & 28.60585 & Năvodari & Taşaul lagoon \\
\hline 10 & 2014 & 44.327967 & 28.68980 & Midia & Harbor \\
\hline 11 & 2012 & 44.326583 & 28.62152 & Navodari & Poarta Alba-Midia Navodari canal \\
\hline 12 & 2015 & 44.221917 & 28.62817 & Constanța & Siutghiol lagoon \\
\hline 13 & 2015 & 44.206967 & 28.63417 & Constanța & Tăbăcărie Lake, city \\
\hline 14 & 2015 & 43.985583 & 28.66670 & Tuzla Cape & Open sea \\
\hline
\end{tabular}




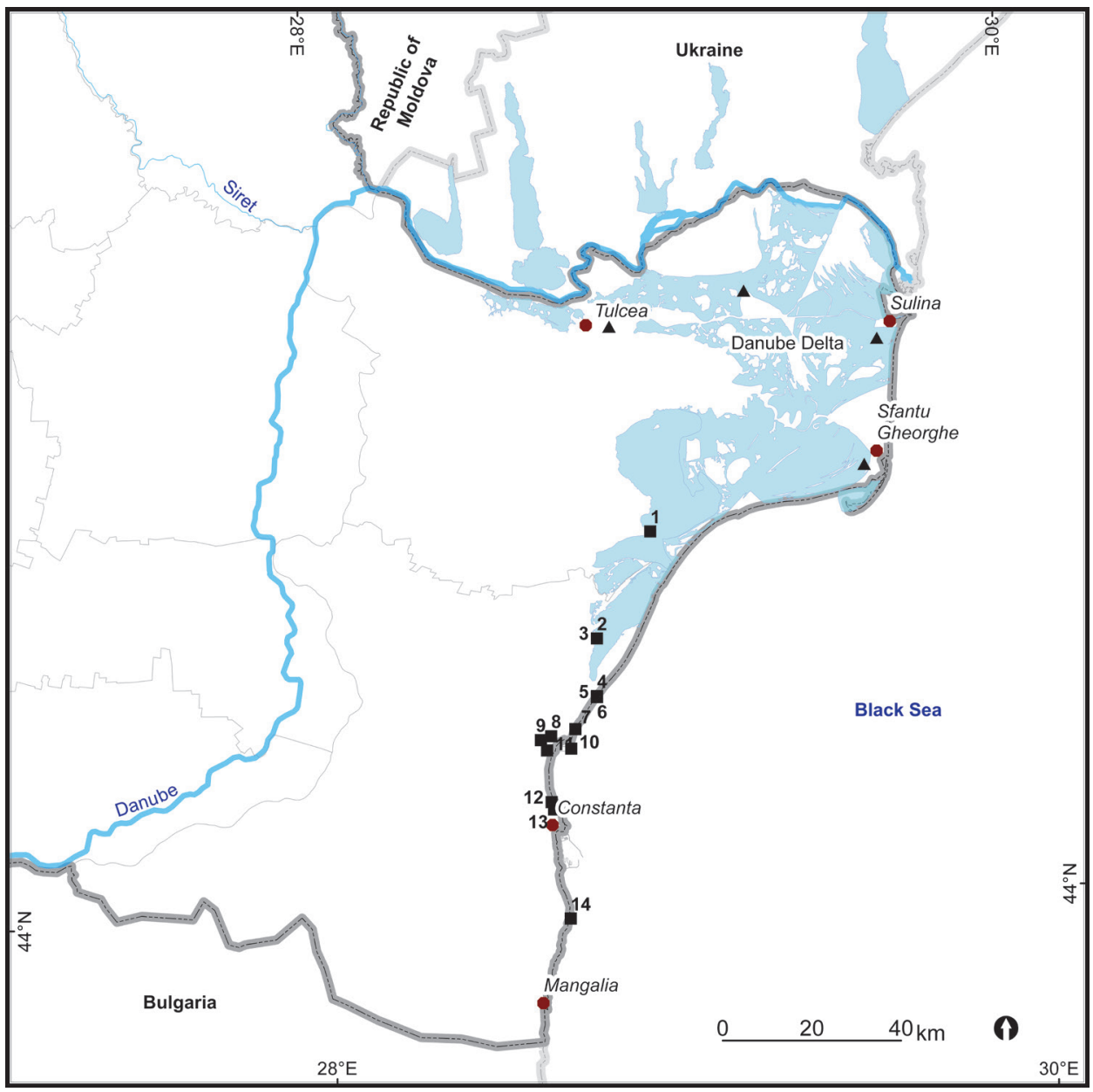

Fig. 1 - Distribution of European otter in the Romanian Black Sea region. Black squares are reported occurrences (IDs in Tab. 1) and black triangles previous records from Murariu \& Munteanu (2005).
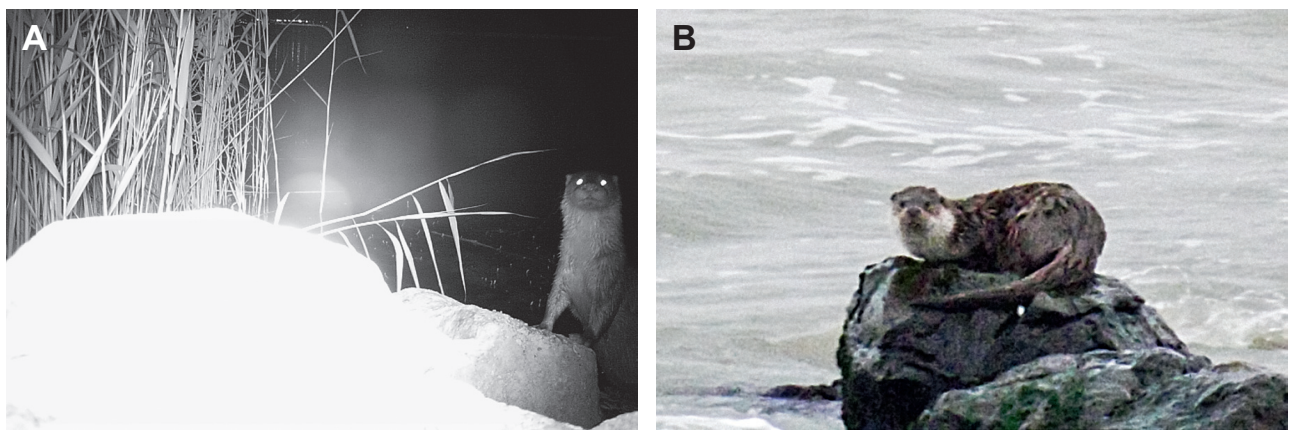

Fig. 2 - European otter individuals on the Romanian Black Sea region: A - Taşaul lagoon (ID 9); B Corbu (ID 7) (Photo: M. Tudor - A; D. Memedemin - B). 

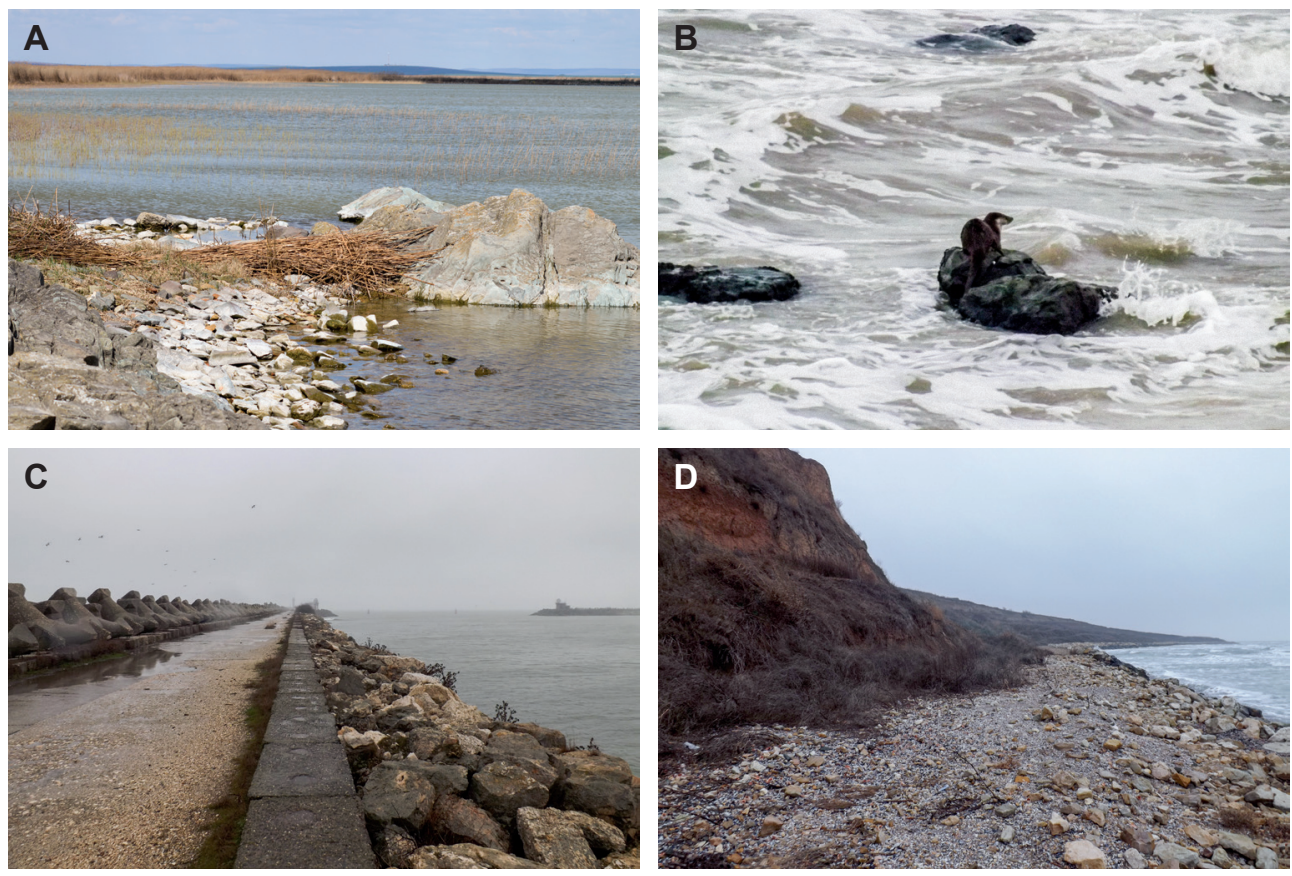

Fig. 3 - Otter habitats on the Romanian Black Sea region: A - Histria (ID 2); B - Corbu (ID 7); C - Midia (ID10); D - Tuzla Cape (ID 14) (Photo: D. Memedemin).

\section{DISCUSSION}

The occurrences reported with this article confirm an extension of European otter range in the Romanian Black Sea coast, probably due to the increasing of the population size from other sources such as the Danube floodplain and the Danube Delta. The absence of reporting the species from seaside is a serious drawback, especially because there are many development projects attempting to change the coastal habitats, such as new resorts and coastal roads. The absence of data from scientific literature can be interpreted by developers as the absence of species, and thus, they can easily claim the lack of impacts on near threatened species such as Lutra lutra.

The European otter is a nocturnal mammal relatively easy to detect and study due to the visible signs such as spraints and tracks (Kruuk, 2006). The knowledge about otter distribution and ecology over most of Europe is very good (Roos et al., 2015), however, this is not the case of Romania. There are very few studies concerning the European otter in Romania, and the distribution data is scarce (e.g., Bouros, 2014). The species has been reported from all Romanian regions, including the Danube Delta. However, the checklists for Dobrogea region do not report the European otter in the Black Sea (e.g., Călinescu, 1934; Murariu, 2005; Murariu \& Munteanu, 2005; Murariu et al., 2009; 2010; Bouroș, 2014), despite the fact that the distribution maps for Bulgaria and Ukraine indicate its presence near the Romanian borders (Roos et al., 2015). Based on the IUCN range map, Murariu \& Munteanu (2005) correctly include the Black Sea coast as a potential habitat for the European otter, although do 
not report occurrences. Because the European otter is easy to spot, the lack of reports might indicate a true absence of species in the past.

\section{ACKNOWLEDGEMENTS}

LR was supported by a grant of the Romanian National Authority for Scientific Research, CNCS - UEFISCDI, project number PN-III-P2-2.1-PED-2016-0568.

\section{REFERENCES}

AUGLANIER, S., P. HAFFNER, A.J. MITCHELL-JONES, F. MOUTOU, J. ZIMA (2008) Mammals of Europe, North Africa and the Middle East. London. A\&C Black Publishers Ltd. 272 pp.

BOUROȘ, G. (2014) Status of the European Otter (Lutra lutra Linnaeus, 1758) in Romania. Romanian Journal of Biology-Zoology , 59: 75-86.

CĂLINESCU, R. (1934) Les mammifères de la Dobrodgea et surtout celles du littoral de la Mer Noire. Annales Scientifiques de l'Université de Jassy, 19: 373-377. (in French)

IOANA-TOROIMAC, G., L. ZAHARIA, G. MINEA (2015) Using Pressure and Alteration Indicators to Assess River Morphological Quality: Case Study of the Prahova River (Romania). Water, $7: 2971-2989$.

KLENKE, R., I. RING, K. S. MÁŇEZ, R. HABIGHORST, V. WEISS, H. WITTMER, B. GRUBER, S. LAMPA, K. HENLE (2013) Otters in Saxony: A Story of Successful Conflict Resolution. In: R.A. Klenke, I. Ring, A. Kranz, N. Jepsen, F. Rauschmayer, K. Henle (eds.): HumanWildlife Conflicts in Europe. Fisheries and Fish-eating Vertebrates as a Model Case. Berlin Heidelberg. Springer-Verlag: 107-140.

KRANZ, A (2000) Otters (Lutra lutra) increasing in Central Europe: from the threat of extinction to locally perceived overpopulation? Mammalia, 64:357-368.

KRUUK, H. (2006) Otters: ecology, behaviour and conservation: ecology, behaviour and conservation. New York. Oxford University Press. 280 pp.

MURARIU, D. (2005) Mammalia (Mamifere) In: N. Botnariuc, V. Tatole (eds.): Cartea Roșie a vertebratelor din România. București. Muzeul Naţional de Istorie Naturală Grigore Antipa: 11-84. (in Romanian)

MURARIU, D., D. MUNTEANU (2005) Fauna României. Carnivora. București. Editura Academiei Române. 223 pp. (in Romanian)

MURARIU, D., I. ATANASOVA, I. RAYKOV, G. CHIȘAMERA (2009) Results on mammal (Mammalia) survey from Bulgarian and Romanian Dobrogea. Travaux du Muséum National d'Histoire Naturelle "Grigore Antipa, 52: 371-386.

MURARIU, D., G. CHIȘAMERA, A. PETRESCU, I. ATANASOVA, I. RAYKOV (2010). Terrestrial vertebrates of Dobrogea-Romania and Bulgaria. Travaux du Muséum National d'Histoire Naturelle" Grigore Antipa", 53: 357-375.

ROOS, A., A. LOY, P. de SILVA, P. HAJKOVA, B. ZEMANOVÁ (2015) Lutra lutra. The IUCN Red List of Threatened Species 2015. Accessed at http://www.iucnredlist.org, 5.01.2016.

*** Commission of the European Communities (2003) Council directive 92/43/EEC of 21 May 1992 on the conservation of natural habitats and of wild fauna and flora. Official Journal of the European Union L 23633 23.9.2003. Brussels. European Commission 1992/95/2003.

*** EUROPEAN TOPIC CENTRE on BIOLOGICAL DIVERSITY (2015) Reporting under Article 17 of the Habitats Directive (period 2007-2012). Accessed at http://bd.eionet.europa.eu/activities/ Reporting/Article_17/Reports_2013, 2.01.2016. 